\title{
ANALISIS DISHARMONISASI ANTARA ASSET FINANCING SERTA KEBIJAKAN PENGELOLAAN INDUSTRI PERTAMBANGAN TERHADAP PDRB DI PROVINSI LAMPUNG
}

\author{
Suwarto $^{1^{*}}$, Ardiansyah Japlani ${ }^{2}$, Abi Melin Monaitaria ${ }^{3}$ \\ Dosen Fakultas Ekonomi dan Bisnis Universitas Muhammadiyah Metro ${ }^{1,2}$ \\ Mahasiswa Fakultas Ekonomi dan Bisnis Universitas Muhammadiyah Metro ${ }^{3}$ \\ wartok_umm@gmail.com
}

\begin{abstract}
ABSTRAK
Dalam rangka memanfaatkan kekayaan sumber daya alam tentunya diperlukan modal sebagai modal khususnya dari perbankan melalui asset financing. Penelitian ini bertujuan untuk mengetahui dan menganalisis. analisis disharmonisasi antara asset financing, kebijakan pengelolaan industri pertambangan terhadap PDRB di Lampung. Pembiayaan modal kerja dan pembiayaan investasi digunakan sebagai variabel independen. Sedangkan, dampak kebijakan kebijakan pengelolaan industri pertambangan menggunakan variabel dummy. Variabel independen dan variabel dummy tersebut dihubungkan dengan variabel dependen yaitu PDRB menggunakan metode regresi data panel dengan model Random Effect(REM) di Lampung. Hasil penelitian menunjukkan bahwa asset financing berpengaruh positif terhadap pertumbuhan ekonomi di Lampung, namun hanya pembiayaan modal kerja yang berpengaruh signifikan. Sementara itu, kebijakan kebijakan pengelolaan industri pertambangan terbukti memberikan pengaruh positif dan signifikan terhadap pertumbuhan ekonomi Lampung. Hasil penelitian ini diharapkan dapat bermanfaat bagi industri, pemerintah maupun regulator sebagai bahan evaluasi mengenai pengaruh asset financing dan kebijakan pengelolaan industri pertambangan terhadap PDRB provinsi Lampung.
\end{abstract}

Kata kunci: Asset Financing, Kebijakan Pengelolaan Industri, PDRB, Lampung

\section{ABSTRACT}

In order to utilize the wealth of natural resources, of course, capital is needed as capital, especially from banks through asset financing. This study aims to determine and analyze. analysis of disharmony between asset financing, mining industry management policies against GDP in Lampung. Working capital financing and investment financing are used as independent variables. Meanwhile, the impact of the mining industry management policy uses a dummy variable. The independent variables and dummy variables are associated with the dependent variable, namely GRDP using the panel data regression method with the Random Effect (REM) model in Lampung. The results showed that asset financing had a positive effect on economic growth in Lampung, but only working capital financing had a significant effect. Meanwhile, the mining industry management policy has proven to have a positive and significant impact on Lampung's economic growth. The results of this study are expected to be useful for industry, government and regulators as an evaluation of the effect of asset financing and mining industry management policies on PDRB in Lampung province.

Keywords: Asset Financing, Industrial Management Policy, GRDP, Lampung 


\section{PENDAHULUAN}

Perbankan memiliki peran yang strategis dalam perekonomian yaitu sebagai motor penggerak pertumbuhan ekonomi melalui aktivitas intermediasi keuangan. Dengan kata lain, bank memiliki fungsi untuk mengalokasikan modal dan melakukan pemantauan untuk memastikan bahwa dana masyarakat disalurkan secara efektif (Utari, Arimurti\&Kurniati, 2012). Efektivitas penyaluran kredit bank memungkinkan rumah tangga untuk dapat melakukan konsumsi dengan lebih baik dan memungkinkan perusahaan untuk dapat melakukan investasi yang tidak cukup jika dilakukan dengan menggunakan modal sendiri (Utari, Arimurti \& Kurniati, 2012).

Pengaruh asset financing terhadap pertumbuhan ekonomi dalam penelitian ini berfokus pada jenis pembiayaan asset financing yang di uji pengaruhnya terhadap pertumbuhan ekonomi Provinsi Lampung sebagai objek penelitian karena Pulau Lampung merupakan kontributor terbesar kelima dalam pertumbuhan ekonomi di Provinsi Lampung yaitu sebesar 11.23 persen yang mana sector pertambangan minyak, gas dan panas bumi merupakan salah satu dari dua sector terbesar penyumbang dari pertumbuhan ekonomi Provinsi Lampung tersebut (BPS, 2020).
Seyogianya, kontribusi penyaluran kredit asset financing terhadap pertumbuhan ekonomi Provinsi Lampung dapat lebih optimal akibat adanya regulasi mengenai hilirisasi industry pertambangan Minerba yang diatur dalam UndangUndang Nomor 4 Tahun 2009 dan secara lebih rinci diatur dalam Peraturan Pemerintah Nomor 1 Tahun 2017 dan Peraturan Menteri ESDM Nomor 5 Tahun 2017 yang berimplikasi pada peningkatan nilai tambah berupa harga produk tambang dan membuka peluang investasi pada sector inik hususnya melalui pembiayaan asset financing.

Namun, keadaan tersebut tidak serta merta diikuti dengan kenaikan penyaluran pembiayaan asset financing pada sector ini dikarenakan sector pertambangan dinilai sebagai sektor yang berisiko karena success rate di bidang pertambangan cukup rendah. Selain itu, sector pertambangan merupakan sektor yang sangat tergantung dengan kondisi ekonomi seperti pengaruh harga minyak dunia (OJK, 2015a). Hal tersebut pada akhirnya memberikan konsekuensi pada tingkat Non-Performing Loan (NPL) perbankan pada sector ini yang cenderung cukup tinggi (OJK, 2020b).

Hal tersebut pada akhirnya memberikan konsekuensi pada kontribusi industry pertambangan dan penggalian 
terhadap PDB Indonesia yang cenderung menunjukkan trend yang menurun. Pada tahun 2015, kontribusi sector pertambangan dan penggalian terhadap PDB tercatat sebesar 7.65 persen. Namun, hingga tahun 2019 kontribusi industry pertambangan dan penggalian terhadap PDB Indonesia hanya mencapai 7.26 persen. Penurunan kontribusi industry pertambangan dan penggalian terhadap PDB Indonesia tersebut disebabkan oleh menurunnya ekspor dan investasi pada sector ini (Kementerian Perindustrian, 2020).

Mengacu pada penjelasan pada paragraf-paragraf diatas, dapat diindikasikan bahwa kontribusi pembiayaan asset financing dan kebijakan hilirisasi industry Minerba terhadap pertumbuhan ekonomi Provinsi Lampung belum dapat dikatakan optimal. Sehingga, penelitian ini dilakukan untuk dapat mengkaji dan membuktikan disharmoni antara das sollen dan das sein tersebut secara ilmiah. Namun, berdasarkan penelitian terdahulu yang digunakan sebagai basis dalam penelitian ini dapat disimpulkan bahwa kajian mengenai topic penelitian ini cenderung tersegmentasi pada dua pembahasan yaitu mengenai pengaruh pembiayaan asset financing terhadap pertumbuhan ekonomi Provinsi Lampung seperti dilakukan oleh Purwanto \& Yanuar (2017); Zumaidah \& Soelistyo (2018);
Mardiana, Robiani \& Susetyo (2019) atau evaluasi dampak kebijakan hilirasasi industry pertambanganMinerbat erhadap pertumbuhan ekonomi secara kualitatif dengan pendekatan yuridis seperti yang dilakukan oleh Ika (2017); Contesa, Sintaningrum \& Rahmatunnisa (2018).

Berdasarkan penelitian terdahulu diatas, terdapat gap penelitian yang dapat di isi melalui penelitian ini sehingga menjadi nilai kebaruan (novelty) dari penelitian ini. Tersegmentasinya pembahasan mengenai topik penelitian ini dalam dua pembahasan menjadi pemicu penelitian ini dilakukan secara komprehensif dengan pendekatan penelitian kuantitatif untuk membahas mengenai pengaruh pembiayaan asset financing dan kebijakan hilirisasi industri Minerba terhadap pertumbuhan ekonomi Provinsi Lampung. Hasil penelitian ini diharapkan dapat bermanfaat bagi perbankan, pemerintah dan regulator perbankan sebagai bahan evaluasi mengenai dampak penyaluran kredit asset financing dan kebijakan hilirisasi industri Minerba terhadap pertumbuhan ekonomi Provinsi Lampung.

\section{METODE PENELITIAN}

Penelitian ini menggunakan desain penelitian berupa explanatory research menggunakan pendekatan penelitian 
kuantitatif dan corak penelitian deduktif yang bertujuan untuk menguji pengaruh variable independen terhadap variable dependennya (Rahi, 2017). Penggunaan pendekatan penelitian kuantitatif dengan corak penelitian deduktif dalam penelitian artinya adalah penelitian ini berusaha untuk memverifikasi hubungan antara variable independen terhadap variable dependen berdasarkan asumsi yang telah ditetapkan dan menggunakan bantuan data penelitian yang selanjutnya dilakukan pengolahan data menggunakan metode statistik yang menghasilkan perspektif sebagai dasar dalam penentuan rekomendasi penelitian (Rahi, 2017).

\section{Data}

Data penelitian yang digunakan dalamp enelitian ini merupakan data sekunder dengan jenis data panel. Yang dimaksud data panel yaitu gabungan antara data crosssection dan time series Provinsi Lampung selama periode triwulan-I 2014 hingga triwulan-I 2020. Pemilihan Provinsi Lampung atas dasar ketersediaan data penelitian, sedangkan pemilihan periode penelitian tersebut atas dasar untuk mengetahui dampak pemberlakuan kebijakan hilirisasi 3 tahun sebelum diberlakukan dan 3 tahun selama diberlakukan sejak tahun 2017 yang diatur secara rinci dalam Peraturan Menteri ESDM Nomor 5 Tahun 2017.

Data penelitian yang digunakan dalam penelitian ini khususnya variabelin dependen yang terdiri dari pembiayaan modal kerja dan pembiayaan investasi yang disalurkan oleh BUK dikumpulkan dengan cara online melalui laporan perekonomian yang dipublikasikan oleh Bank Indonesia. Sementara itu, data penelitian yang termasuk dalam variable dependen yaitu PDRB ADHK 2010 menurut pengeluaran sebagai proxy dari pertumbuhan ekonomi dikumpulkan secara online melalui publikasi Badan Pusat Statistik masingmasing provinsi. Sedangkan, variable dummy hiliriasi industry Minerba dinotasikan dengan 0 yaitu sebelum pemberlakukan kebijakan mengenai hilirisasi industry Minerba yang secara rinci diatur melalui Peraturan Menteri ESDM Nomor 5 Tahun 2017 dan 1 yaitu selama pemberlakukan kebijakan mengenai hilirisasi industry Minerba yang secara rinci diatur melalui Peraturan Menteri ESDM Nomor 5 Tahun 2017.

\section{Teknik Analisis Data}

Setelah dilakukan pengumpulan data secara lengkap, maka selanjutnya dapat dilakukan teknik analisis data. Teknik analisis data yang digunakan dalam penelitian ini yaitu regresi data panel dengan model Random 
Effect (REM). Mengingat data panel merupakan gabungan antara cross-section dan time series, maka model regresi data panel dapat dituliskan sebagai berikut (Nachrowi \& Usman, 2018):

$Y_{i t}=\alpha+\beta_{1} X_{1 i t}+\beta_{2} X_{2 i t}+\beta_{3} X_{3 i t}+$ $\varepsilon_{i t}(1)$

dimana:

$Y \quad=$ pertumbuhan ekonomi dengan proxy PDRB ADHK 2010 menurut pengeluaran pada

Provinsi Lampung (Triliun Rupiah)

$\alpha \quad=$ konstanta

$X_{1}=$ pembiayaan modal kerja (Triliun Rupiah)

$X_{2}=$ pembiayaan investasi (Triliun Rupiah)

$X_{3}=$ dummy hilirisasi industri

Minerba

(0 sebelum diberlakukan kebijakan mengenai hilirisasi industry Minerba yang secara rinci diatur melalui Peraturan Menteri ESDM Nomor 5 Tahun 2017 dan 1 yaitu selama pemberlakukan kebijakan mengenai hilirisasi Industry Minerba yang secara rinci diatur melalui Peraturan Menteri ESDM Nomor 5 Tahun 2017)

$i \quad=1,2, \ldots \ldots ., \mathrm{N}$ (Provinsi Lampung)

$t \quad=1,2, \ldots \ldots ., \mathrm{T}$ (selama periode triwulan-I 2014 hingga triwulan-I 2020)
$\mathrm{N} \times \mathrm{T}=5 \times 25=125$ (banyaknya data panel)

$e=$ error term

Namun, sebelum ditetapkan dalam penelitian ini menggunakan regresi data panel dengan model REM, maka perlu terlebih dahulu dilakukan pemilihan model terbaik menggunakan Uji Chow untuk memilih model terbaik antaraCommon Effect Model (CEM) dan Fixed Effect Model (FEM) serta Uji Hausman untuk memilih model terbaik antara FEM dan REM. Penentuan keputusan pada Uji Chow didasarkan pada nilai probabilitas crosssectionF dimana jika kurangdaria 0.05 maka model terbaik adalah FEM dan sebaliknya jika lebih dari $\alpha 0.05$ maka model terbaik adalah CEM. Sedangkan, penentuan keputusan pada Uji Hausman didasarkan pada nilai probabilitas crosssection random dimana jika kurang dari $\alpha$ 0.05 maka model terbaik adalah FEM dan sebaliknya jika lebih dari $\alpha 0.05$ maka model terbaik adalah REM (Susanti\&Nidar, 2016).

Selain itu, untuk memastikan model regresi yang digunakan dalam penelitian ini memenuhi asumsi Best Linear Unbias Estimator (BLUE), maka perlu dilakukan uji asumsi klasik yaitu multikolinieritas dan heteroskedastisitas. Uji asumsi klasik dalam regresi data panel tidak perlu dilakukan secara keseluruhan seperti pada regresi 
linier berganda karena permasalahan autokorelasi umumnya hanya terjadi pada data time series dan normalitas data tidak menjadi syarat utama pada asumsi BLUE sehingga uji asumsi klasik yang perlu dilakukan pengujian hanya multikolinieritas dan heteroskedastisitas (Susanti \& Nidar, 2016)..

\section{HASIL DAN PEMBAHASAN}

Tahap pertama dalam analisis regresi data panel adalah melakukan pengujian dengan menggunakan model CEM, FEM dan REM. Output pengujianregresi data panel menggunakan model CEM, FEM dan REM ditunjukkan dalam table sebagai berikut:

Tabel 1. Output PengujianRegresi Data Panel MenggunakanMetode CEM, FEM dan REM

\begin{tabular}{cccc}
\hline Variabel & CEM & FEM & REM \\
\hline C & 1.7214 & 2.7777 & 2.7768 \\
& 82 & 12 & 25 \\
& $(0.0000)$ & $(0.0000)$ & $(0.0000)$ \\
& & & \\
LOGMODAL_ & 0.6246 & 0.1325 & 0.1326 \\
KERJA & 40 & 24 & 73 \\
& $(0.0026)$ & $(0.0000)$ & $(0.0000)$
\end{tabular}

$\begin{array}{cccc}\text { LOGINVEST } & - & 0.0032 & 0.0035 \\ \text { ASI } & 0.0827 & 82 & 46 \\ & 58 & & \end{array}$

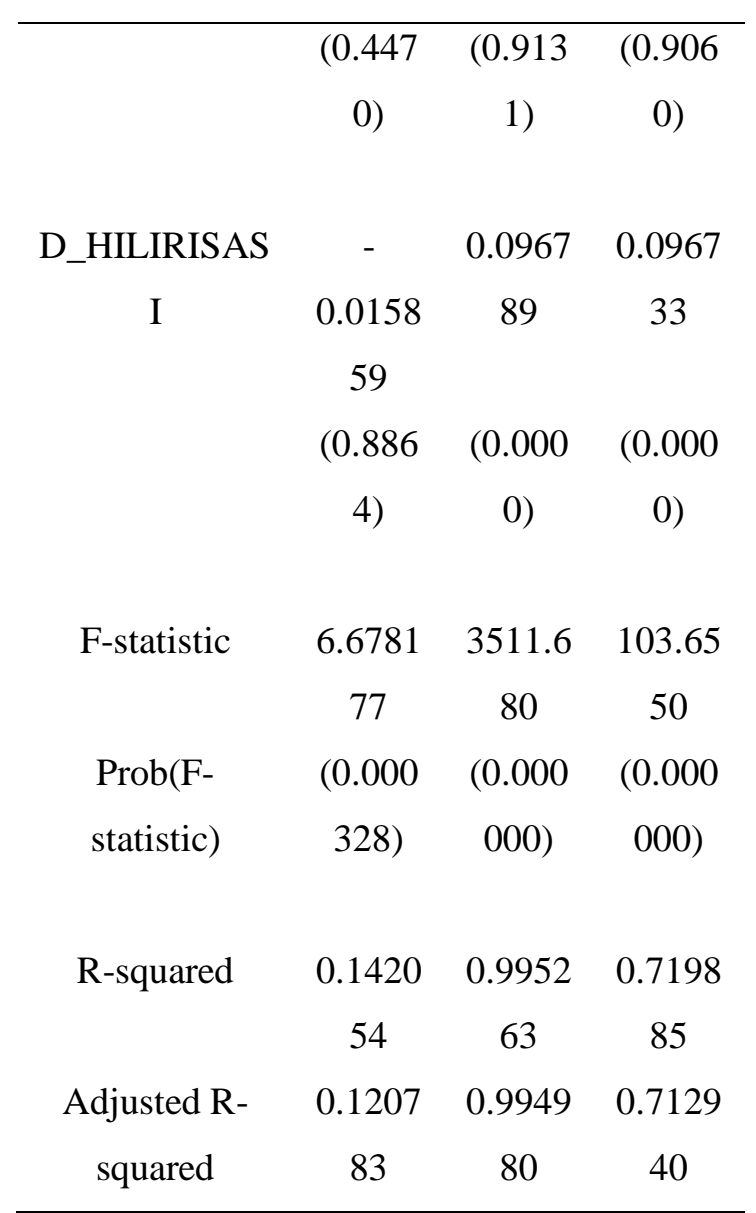

Sumber: DiolahPeneliti (2020)

Setelah dilakukan pengujian dengan menggunakan tiga model dalam regresi data panel yaitu CEM, FEM dan REM, maka selanjutnya dapat dilakukan pemilihan model terbaik dari ketiga output yang dihasilkan. Pemilihan model terbaik dilakukan dengan melakukan Uji Chow dan Hausman yang outputnya ditunjukkan dalam table sebagaiberikut: 
Tabel 2. Output Pemilihan Model RegresiMenggunakan Uji Chow dan Hausman

\begin{tabular}{cccc}
\hline \multicolumn{4}{c}{ Output Chow Test } \\
\hline $\begin{array}{c}\text { Effects } \\
\text { Test }\end{array}$ & Statistic & d.f. & Prob. \\
\hline Cross- & 5268.29976 & $(4,117$ & 0.000 \\
section F & 2 & ) & 0 \\
Cross- & & & \\
section & & \\
Chi- & & & 0.000 \\
square & 649.890014 & 4 & 0 \\
\hline \multicolumn{4}{c}{ Output Hausman Test } \\
\hline Test & Chi-Sq. & Chi- & Prob. \\
Summar & Statistic & Sq. & \\
y & & d.f. & \\
\hline Cross- & & & \\
section & & & 0 \\
random & 0.000000 & 3 & 000 \\
\hline
\end{tabular}

Sumber: DiolahPeneliti (2020)

Melalui table diatas dapat ditunjukkan bahwa berdasarkan output Uji Chow yang berfungsi untuk memilih model terbaik antara CEM dan FEM dapat disimpulkan bahwa model terbaik adalah FEM yang ditunjukkan melalui nilai probabilitas Cross-section $F<\alpha 0.05$. Selanjutnya, dapat dilakukan pemilihan model antara FEM dan REM melalui Uji Hausman. Berdasarkan Uji Hausman diketahuinilai probabilitas Cross-section random $>\alpha 0.05$ atau dapat disimpulkan model terbaikantara FEM dan REM adalah REM.

Berdasarkan output pemilihan model regresimenggunakan Uji Chow dan Hausman diketahui bahwa model terbaik yang terpilih dalam penelitian ini adalah REM. Selain itu, berdasarkan uji asumsi klasik dinyatakan bahwa model yang dihasilkan telah memenuhi kriteria sebagai prediktor atau BLUE sehingga selanjutnya dapat dilakukan interpretasi dan analisis terhadap model regresi yang dihasilkan. Model regresi yang digunakan dalam penelitian ini yaitu sebagai berikut:

$$
\begin{aligned}
& P D R B_{i t}=2.776825+0.132673 X_{1 i t}+ \\
& 0.003546 X_{2 i t}+0.096733 X_{3 i t}
\end{aligned}
$$

Hipotesis:

$\mathrm{H}_{0}: \mathrm{b}_{1}, \mathrm{~b}_{2}, \mathrm{~b}_{3}=0$ (X tidakmemengaruhi $\left.\mathrm{Y}\right)$ $\mathrm{H}_{1}: \mathrm{b}_{1}, \mathrm{~b}_{2}, \mathrm{~b}_{3} \neq 0$ (X memengaruhi $\left.\mathrm{Y}\right)$

Dari model diatasdapatdilakukaninterpretasisecaraparis al (T-statistic) maupun secara simultan (Fstatistic) yaitu sebagai berikut:

1. Nilai konstanta atau $b_{0}$ sebesar 2.776825 artinya adalah rata-rata pertumbuhan ekonomi Provinsi Lampung sebelum diberlakukannya kebijakan hilirisasi industry Minerba yang diatur secara rinci dalam Peraturan Menteri ESDM Nomor 5 Tahun 2017 tentang Peningkatan Nilai Tambah Mineral melalui Kegiatan Pengolahan dan Pemurnian Mineral di Dalam Negeri. 
2. Nilai $b_{1}$ variabel pembiayaan modal kerja sebesar 0.132673 artinya adalah setiap terjadi peningkatan terhadap penyaluran pembiayaan modal kerja oleh BUK sebesar Rp 1 Triliun maka akan meningkatkan pertumbuhan ekonomi Provinsi Lampung sebesar 0.133 persen. Berdasarkan output pengujian regresi data panel dengan model REM diketahui nilai $p$-valuesebesar 0.0000 $<\alpha$ 0.05, maka sesuai hipotesis dapat diputuskan bahwa $\mathrm{H}_{0}$ ditolak atau dengan kata lain dapat disimpulkan bahwa pembiayaan modal kerja berpengaruh positif dan signifikan terhadap pertumbuhan ekonomi Provinsi Lampung.

3. Nilai $b_{2}$ variabel pembiayaan investasi sebesar 0.003546 artinya adalah setiap terjadi peningkatan terhadap penyaluran pembiayaan investasi oleh BUK sebesar Rp 1 Triliun maka akan meningkatkan pertumbuhan ekonomi Provinsi Lampung sebesar 0.0035 persen. Berdasarkan output pengujian regresi data panel dengan model REM diketahui nilaipvalue sebesar $0.9060>\alpha 0.05$, maka sesuai hipotesis dapat diputuskan bahwa $\mathrm{H}_{0}$ diterima atau dengan kata lain dapat disimpulkan bahwa pembiayaan investasi berpengaruh positif namunt idaksignifikan terhadap pertumbuhan ekonomi Provinsi Lampung.

4. Nilai $b_{3}$ variabel dummy hilirisasi industry Minerba sebesar0.096733 artinya adalah rata-rata pertumbuhan ekonomi Provinsi Lampung selama diberlakukannya kebijakan mengenai hilirisasi industry Minerba yang secara rinci diatur melalui Peraturan Menteri ESDM Nomor 5 Tahun 2017 lebih tinggi dibandingkan dengan rata-rata pertumbuhan ekonomi Provinsi Lampung sebelum diberlakukannya kebijakan mengenai hilirisasi industri Minerba. Berdasarkan output pengujian regresi data panel dengan model REM diketahui bahwa nilai p-value sebesar $0.0000<\alpha 0.05$, maka sesuai hipotesis dapat diputuskan bahwa $\mathrm{H}_{0}$ ditolak atau dengan kata lain dapat disimpulkan bahwa terdapat perbedaan positif dan signifikan antara pertumbuhan ekonomi Provinsi Lampung selama diberlakukannya kebijakan mengenai hilirisasi industri Minerba dibandingkan dengan pertumbuhan ekonomi Provinsi Lampung sebelum diberlakukannya kebijakan mengenai hilirisasi industri Minerba.

5. Berdasarkan pengujian F-statistic diketahui nilai probabilitas $F$-statistic sebesar $0.000000<\alpha \quad 0.05$ yang artinya secara simultan pembiayaan produktif BUK dan pemberlakuan aturan mengenai hilirisasi industri Minerba berpengaruh signifikan terhadap pertumbuhan ekonomi Provinsi Lampung.

Nilai $R$-squared sebesar 0.7199 artinya adalah variabel independen yang digunakan 
dalam penelitian ini mampu menjelaskan variasi variabel dependennya sebesar 71.99 persen, sementara sisanya sebesar 28.01 persen dijelaskan oleh variabel lain yang tidak diperhitungkan dalam model penelitianini.

\section{SIMPULAN}

Berdasarkan pada hasil analisis data dan pembahasan yang telah dilakukan dapa t disimpulkan bahwa se cara simultan pembiayaan produktif perbankan dan kebijakan hilirisasi industry Minerba berpengaruh signifikan terhadap pertumbuhan ekonomi Provinsi Lampung selama periode penelitian. Namun, secara parsial hanya pembiayaan modal kerja yang berpengaruh positif dan signifikan terhadap pertumbuhan ekonomi Provinsi Lampung. Sedangkan, pembiayaan investasi diketahui berpengaruh positif namun tidak signifikan terhadap pertumbuhan ekonomi Provinsi Lampung. Selain itu, secara parsial hasil penelitian ini dapat membuktikan bahwa kebijakan hilirisasi industry Minerba berpengaruh positif dan signifikan terhadap pertumbuhan ekonomi Provinsi Lampung.

Berdasarkan pada pembahasan yang telah dilakukan, berikut rekomendasi yang dapat diajukan yang ditujukan baik bagi industri perbankan, regulator perbankan maupun pemerintah. Pertama, meskipun diakui di sektor pertambangan memilik irisikokredit yang relatif tinggi, namun perbankan hendaknya tidak menutup diri untuk menyalurkan pembiayaan produktif pada sektor ini mengingat kebijakan hilirisasi membutuhkan dukungan dana investasi yang besar khususnya untuk pembangunan pabrik smelter.

Kedua, peneliti mengapresiasi adanya PBI Nomor 22/4/PBI/2020 tentang Insentif bagi Bank yang Memberikan Penyediaan Dana untuk Kegiatan Ekonomi TertentuGuna Mendukung Penanganan Dampak Perekonomian Akibat Wabah Virus Corona. Namun, untuk meningkatkan penyaluran pembiayaan produktif khususnya pada sektor pertambangan, hendaknya regulator perbankan dapat mengaturinovasi pada model investasi seperti pengaturan dalam bentuk bank investasi.

\section{DAFTAR PUSTAKA}

\section{Jurnal online}

Contesa, M., Sintaningrum., \&Rahmatunnisa, M. (2018). Smelter: Inkonsistensi Kebijakan, Kendala dan Dampak di Indonesia. Responsive, 1(1), 6-11.

Ika, S. (2017). Kebijakan Hilirisasi Mineral: Reformasi Kebijakan untuk Meningkatkan Penerimaan Negara. Kajian Ekonomi\&Keuangan, 1(1), 42 67.

Mardiana, S., Robiani, B., \&Susetyo, D. (2019). Pengeluaran Belanja Modal Pemerintah dan Kredit Modal Kerjaterhadap Pertumbuhan Ekonomi Provinsi di Pulau Sumatra. Jemasi: Jurnal Ekonomi 
Manajemen dan Akuntansi, 15(2), 122 140.

Nachrowi, N. D., \& Usman, H. (2018). PendekatanPopuler dan PraktisEkonometrikauntukAnalisisEkon omi dan Keuangan. Jakarta: Lembaga Penerbit FakultasEkonomi Universitas Indonesia.

Purwanto., \&Yanuar, F. A. R. (2017). Kontribusi Pembiayaan yang Diberikan oleh Perbankan Syariah terhadap Produk Domestik Regional Bruto di Pulau Jawa dan Sumatra Tahun 2012 - 2016. Iqtishadia: Jurnal Ekonomi dan Perbankan Syariah, 4(2), 214 - 234.

Rahi, S. (2017). Research Design and Methods: A Systematic Review of Research Paradigms, Sampling Issues and Instruments Development. International Journal of Economics \& Management Sciences, 6(2), $1-5$.

Susanti, L., \&Nidar, S. R. (2016). Corporate Board and Firm Value: Perspective TwoTier Board System in Indonesia. International Journal of Scientific \& Technology, 5(5), $300-305$.

Utari, G. A. D., Arimurti, T., \&Kurniati, I. N. (2012). PertumbuhanKredit Optimal. Buletin Ekonomi Moneter dan Perbankan, 15(2), 1 - 36.

Wibowo, P. P. (2013). Branchless Banking Setelah Multilicense: Ancaman atau Kesempatan bagi Perbankan Nasional. Paper Disampaikan Dalam Rangka Memenuhi Salah Satu Persyaratan Staf Pimpinan Bank Indonesia (SESPIBI) Angkatan XXXI.

Unik Desthiani, (2020). Peningkatan Motivasi dan Kompetensi Latihan Dasar Kepemimpinan melalui pendekatan Edutainment. Jurnal Sekretari, Universitas Pamulang.

Waluyo, (2019). Pengaruh Gaya Komunikasi Organisasi Terhadap Prestasi Kerja Pegawai Pada Biro Komunikasi Layanan
Masyarakat Kemdikbud Jakarta. Jurnal Sekretari. Universitas Pamulang

\section{Ensiklopedia}

Badan Pusat Statistik. (2020). Pertumbuhan Ekonomi Indonesia Triwulan II-2020.

BPS: Berita Resmi Statistik No. 64/08/Th. XXIII, 5 Agustus 2020.

Bank Indonesia. (2020). Kajian Ekonomi dan Keuangan Regional. Laporan Nusantara Mei 2020, 15(2), 1 - 80 .

Kementerian Perindustrian. (2020). Analisis Perkembangan Industri Indonesia Edisi I-2020. Jakarta: Kementerian Perindustrian.

Otoritas Jasa Keuangan. (2015a). Potensi Pertumbuhan Ekonomi ditinjau dari Penyaluran Kredit Perbankan Kepada Sektor Prioritas Ekonomi Pemerintah. Jakarta: Otoritas Jasa Keuangan, Departemen Pengembangan Pengawasan dan Manajemen Krisis, Divisi Analisis Profil Industri.

Otoritas Jasa Keuangan. (2020b). Laporan Profil Industri Perbankan Triwulan I 2020. Jakarta: Otoritas Jasa Keuangan.

Peraturan Menteri Energi dan SumberDaya Mineral Republik Indonesia Nomor 05 Tahun 2017 tentangPeningkatan Nilai Tambah Mineral melalui Kegiatan Pengolahan dan Pemurnian Mineral di Dalam Negeri.

PeraturanPemerintahRepublik Indonesia Nomor 1 Tahun 2017 tentang Perubahan Keempat Atas Peraturan Pemerintah Nomor 23 Tahun 2010 tentang Pelaksanaan Kegiatan Usaha Pertambangan Mineral dan Batubara.

UndangUndangRepublik Indonesia Nomor 4 Tahun 2009 tentang Pertambangan Mineral dan Batubara. 